\title{
EFEKTIFITAS MODEL PEMBELAJARAN DISCOVERY LEARNING DALAM MENINGKATKAN HASIL BELAJAR PAI DI SEKOLAH MENENGAH PERTAMA \\ Rusli
}

\author{
Guru SMP Negeri 1 Darul Aman, Kec. Darul Aman, Kab. Aceh Timur \\ wardani_hayatul@yahoo.com
}

\begin{abstract}
This study aims to improve student learning outcomes in learning PAI material to recognize the attributes of God through the application of the Discovery Learning Model VII-A grade students of SMP Negeri 1 Darul Aman semester I of the 2017-2018 academic year. This research is a Classroom Action Research (CAR) which is carried out in two cycles, in each cycle, the researcher uses several research procedures including, planning, implementing, observing and reflecting. Data collection techniques used in research through tests of student learning outcomes that are used to determine student learning completeness after action. Student learning outcomes can be declared successful when learning outcomes have reached KKM of 70. Classically a class has been completed learning when achieving classical completeness of $85 \%$. With the implementation of the Discovery Learning Learning Model. The results showed, in the first cycle (one) the average value of students amounted to 60.67 and mastery learning reached $51.61 \%$.

Keywords: PAI Learning Outcomes, Material Knowing the Attributes of God, Discovery Learning Learning Model
\end{abstract}

\section{ABSTRAK}

Penelitian ini bertujuan untuk meningkatkan hasil belajar siswa dalam pembelajaran PAI materi mengenal sifat-sifat Allah melalui penerapan Model Pembelajaran Discovery Learning siswa kelas VII-A SMP Negeri 1 Darul Aman semester I tahun pelajaran 2017-2018. Penelitian ini merupakan Penelitian Tindakan Kelas (PTK) yang dilaksanakan dalam dua siklus, pada masing-masing siklus, peneliti menggunakan beberapa prosedur penelitian meliputi, perencanaan, pelaksanaan, pengamatan dan refleksi. Teknik pengumpulan data yang digunakan dalam penelitian melalui tes hasil belajar siswa yang digunakan untuk mengetahui ketuntasan belajar siswa setelah dilakukan tindakan. Hasil belajar siswa dapat dinyatakan berhasil bila hasil belajar telah mencapai KKM sebesar 70. Secara klasikal suatu kelas telah tuntas belajar bila mencapai ketuntasan klasikal sebesar 85\%. Dengan diterapkannya Model Pembelajaran Discovery Learning. Hasil penelitian menunjukkan, pada siklus I (satu) nilai rata-rata siswa berjumlah 60,67 dan ketuntasan belajar mencapai 51,61\%. Hasil ini menunjukkan peningkatan dari kondisi awal yang nilai rata-ratanya hanya 4,83 dan ketuntasan belajar baru 19,35\%. Sedangkan pada siklus II (dua) nilai rata-rata siswa mencapai 70,66 dan ketuntasan belajar mencapai 87,10\%. Persentase ketuntasan belajar secara klasikal ini menunjukkan pencapaian yang melampaui indikator keberhasilan penelitian yang telah ditetapkan sebesar $85 \%$. Kesimpulan dari penelitian ini adalah penerapan Model Pembelajaran Discovery Learning dapat meningkatkan hasil belajar PAI materi mengenal sifatsifat Allah siswa kelas VII-A SMP Negeri 1 Darul Aman semester I tahun pelajaran 2017-2018.

Kata Kunci: Hasil Belajar PAI, Materi Mengenal Sifat-Sifat Allah, Model Pembelajaran Discovery Learning

\section{Author correspondence}

Email:wardani_hayatul@yahoo.com Available online at http://ejurnalunsam.id/index.php/jsnbl/index 
SEUNEUBOK LADA

Jurnal Ilmu-Ilmu Sejarah, Sosial, Budaya dan Kependidikan, 7 (1), 2020: 107-117

ISSN : 2356-0770

e-ISSN : 2685-2705

\section{A. PENDAHULUAN}

Semua manusia di dalam hidupnya di dunia ini, selalu membutuhkan adanya suatu pegangan hidup yang disebut Agama. Mereka merasakan bahwa dalam jiwanya ada suatu perasaan yang mengakui adanya Dzat Yang Maha Kuasa, tempat mereka berlindung dan tempat mereka memohon pertolongan-Nya. Hal semacam ini terjadi pada masyarakat yang masih primitive maupun pada masayarakat yang sudah modern. Mereka akan merasa tenang dan tenteram hatinya kalau mereka dapat mendekat dan mengabdikan diri kepada Dzat Yang Maha Kuasa. Karena itu manusia selalu berusaha untuk mendekatkan diri kepada Tuhan, hanya saja cara mereka mengabdi dan mendekatkn diri kepada Tuhan itu berbeda sesuai dengan agama yang dianutnya. Itulah sebabnya, bagi orang Muslim diperlukan adanya Pendidikan Agama Islam, agar dapat mengarahkan fitrah mereka tersebut kearah yang benar, sehingga mereka akan dapat mengabdi dan beribadah sesuai dengan ajaran Islam. Tanpa adanya Pendidikan Agama dari satu generasi ke generasi berikutnya, maka orang akan semakin jauh dari Agama yang benar.

Tujuan dari Pendidikan Agama adalah untuk membimbing anak agar mereka menjadi orang Muslim sejati, beriman teguh, beramal sholeh dan berakhlak mulia serta berguna bagi masyarakat, Agama dan Negara, (Euharini, dkk. 2007: 25). Titik sentral yang harus dicapai oleh setiap kegiatan belajar mengajar adalah tercapainya tujuan pengajaran. Apa pun yang termasuk perangkat program pengajaran dituntut secara mutlak untuk menunjang tercapainya tujuan. Guru tidak dibenarkan mengajar dengan kemalasan. Anak didik pun diwajibkan mempunyai kreativitas yang tinggi dalam belajar, bukan selalu menanti perintah guru. Kedua unsur manusiawi ini juga beraktivitas tidak lain karena ingin mencapai tujuan secara efektif dan efisien.

Salah satu indikator pendidikan berkualitas merupakan perolehan nilai hasil belajar siswa. Nilai hasil belajar siswa dapat lebih ditingkatkan apabila pembelajaran berlangsung secara efektif dan efisien dengan ditunjang oleh tersedianya sarana dan prasarana pendukung serta kecakapan guru dalam pengelolaan kelas dan pengusaan materi yang memadai.

Tolok ukur keberhasilan pembelajaran pada umumnya adalah prestasi belajar.Prestasi belajar Pendidikan Agama Islam (PAI) di kelas VII-A SMPN 1 Darul Aman Kabupaten Aceh Timur untuk beberapa kompetensi dasar umumnya menunjukkan nilai yang rendah. Hal ini standar kompetensi dan kompetensi dasar PAI kelas VII memang sarat akan materi, di samping cakupannya luas dan perlu hafalan. Jika dilihat dari hasil ulangan harian sebagian besar masih di bawah kriteria ketuntasan minimal (KKM) yaitu sebesar 83,34\%, hanya 16,67\% siswa yang telah memenuhi standar ketuntasan minimal. Dengan rata-rata kelas sebesar 4,83 . 
SEUNEUBOK LADA

Jurnal Ilmu-Ilmu Sejarah, Sosial, Budaya dan Kependidikan, 7 (1), 2020: 107-117

ISSN : 2356-0770

e-ISSN : 2685-2705

Rendahnya prestasi belajar PAI di kelas kelas VII-A SMPN 1 Darul Aman Kabupaten Aceh Timur dimungkinkan juga karena guru belum menggunakan metode atau pun media pembelajaran serta mendesain skenario pembelajaran yang disesuaikan dengan karakteristik materi maupun kondisi siswa sehingga memungkinkan siswa aktif dan kreatif. Namun sebaliknya kecenderungan guru menggunakan model pembelajaran konvensional yang bersifat satu arah, cenderung kering dan membosankan. Kegiatan pembelajaran masih didominasi guru. Siswa sebagai obyek bukan subyek bahkan guru cenderung membatasi partisipasi dan kreatifitas siswa selama proses pembelajaran.

Bertumpu pada kenyataan tersebut untuk merangsang dan meningkatkan peran aktif siswa baik secara individual dan kelompok terhadap proses pembelajaran PAI maka masalah ini harus ditangani dengan mencari model pembelajaran yang tepat dan sesuai dengan materi yang diajarkan. Guru sebagai pengajar dan fasilitator harus mampu melakukan pembelajaran yang menyenangkan, menggairahkan sehingga akan diperoleh hasil yang maksimal. Kenyataan selama ini kegiatan belajar mengajar masih didominasi guru yaitu kegiatan satu arah dimana penuangan informasi dari guru ke siswa dan hanya dilaksanakan dan berlangsung di sekolah, sehingga hasil yang dicapai siswa hanya mampu menghafal fakta, konsep, prinsip, hukum-hukum, teori hanya pada tingkat ingatan.

Upaya harus dilakukan untuk memulai tuntutan lulusan yang kompetitif di era pembangunan yang berbasis ekonomi dan globalisasi adalah menyelaraskan kegiatan pembelajaran dengan nuansa Kurikulum 2013 yang diindikasikan dengan keterlibatan siswa secara aktif dalam membangun gagasan/pengetahuan oleh masing-masing individu baik di dalam maupun diluar lingkungan sekolah dengan metode mengajar yang dapat membuat siswa kreatif dalam proses pembelajaran. Salah satu diantaranya adalah pembelajaran Discovery Learning.

Model pembelajaran penemuan (discovery learning) diartikan sebagai proses pembelajaran yang terjadi ketika siswa tidak disajikan informasi secara langsung tetapi siswa dituntut untuk mengorganisasikan pemahaman mengenai informasi tersebut secara mandiri. Siswa dilatih untuk terbiasa menjadi seorang yang saintis (ilmuan). Mereka tidak hanya sebagai konsumen, tetapi diharapkan pula bisa berperan aktif, bahkan sebagai pelaku dari pencipta ilmu pengetahuan Hosnan (2014: 282).

Dengan pembelajaran Discovery Learning diharapkan siswa dapat menggali dan menemukan pokok materi secara bersama-sama dalam kelompok atau secara individu. Penerapan Pembelajaran discovery learning, merupakan tindakan pemecahan masalah yang ditetapkan dalam upaya meningkatkan hasil belajar PAI khususnya kompetensi dasar Mengenal Sifat-Sifat Allah, bagi siswa kelas VII-A SMPN 1 Darul Aman Kabupaten Aceh Timur sehingga diharapkan dapat 
SEUNEUBOK LADA

Jurnal Ilmu-Ilmu Sejarah, Sosial, Budaya dan Kependidikan, 7 (1), 2020: 107-117

ISSN : 2356-0770

e-ISSN : 2685-2705

membantu para guru untuk mengembangkan gagasan tentang strategi kegiatan pembelajaran yang efektif dan inovatif serta mengacu pada pencapaian kompetensi individual masing-masing peserta didik.

Bertitik tolak daripada latar belakang masalah di atas, maka penulis tertarik untuk mengangkat suatu penulisan artikel yang berjudul "Efektifitas Model Pembelajaran Discovery Learning dalam Meningkatkan Hasil Belajar PAI di Sekolah Menengah Pertama”.

\section{B. TINJAUAN PUSTAKA}

\section{Hakekat Belajar}

Belajar merupakan usaha yang dilakukan setiap manusia dalam rangka untuk mencapai sesuatu yang ingin dicapai. Menurut Dimyati dan Mudjiono (2002: 232) menyimpulkan tentang belajar yaitu: 1) belajar itu membawa perubahan; 2) perubahan itu pada pokoknya adalah didapatkannya kecakapan baru; 3) perubahan itu terjadi karena usaha dengan sengaja. Belajar adalah suatu proses di mana suatu tindakan muncul atau berubah karena adanya respons terhadap sesuatu situasi (Hidayat, 2002:15). Hal ini yang juga terkait dengan belajar adalah pengalaman, pengetahuan yang berbentuk interaksi dengan orang lain atau lingkungannya.

Dalam penelitian ini, belajar adalah suatu proses yang ditandai dengan perubahan pada diri siswa, dan perubahan itu merupakan hasil belajar yang melibatkan segi jasmani dan rohani yang menghasilkan perubahan-perubahan dalam hal pengetahuan, pemahaman, ketrampilan, sikap dan tingkah laku, serta semua aspek yang ada dalam individu.

\section{Hasil Belajar}

Hasil belajar siswa dalam hal ini meliputi tiga aspek, yaitu aspek kognitif, aspek afektif dan aspek psikomotorik. 1) aspek kognitif, kemampuan kognitif yang meliputi: pengetahuan, pemahaman, penerapan, analisis, sintesis, dan evaluasi. 2) Aspek afektif, kemampuan afektif meliputi penerimaan, partisipasi, penilaian,dan penentuan sikap, organisasi, dan pembentukan pola hidup. 3) Aspek psikomotorik, kemampuan psikomorik meliputi: persepsi, kesiapan, gerakan terbimbing, gerakan terbiasa, gerakan kompleks, gerakan penyesuaian dan kreativitas (Hamalik, 2003: 160).

\section{Pembelajaran Discovery Learning}

a. Pengertian Discovery Learning

Model pembelajaran penemuan (discovery learning) diartikan sebagai proses pembelajaran yang terjadi ketika siswa tidak disajikan informasi secara langsung tetapi siswa dituntut untuk mengorganisasikan pemahaman mengenai informasi tersebut secara mandiri. Siswa dilatih untuk terbiasa menjadi seorang 
SEUNEUBOK LADA

Jurnal Ilmu-Ilmu Sejarah, Sosial, Budaya dan Kependidikan, 7 (1), 2020: 107-117

ISSN : 2356-0770

e-ISSN : 2685-2705

yang saintis (ilmuan). Mereka tidak hanya sebagai konsumen, tetapi diharapkan pula bisa berperan aktif, bahkan sebagai pelaku dari pencipta ilmu pengetahuan Lie (2002: 282).

Menurut Ibrahim (2012: 32), pembelajaran Discovery Learning adalah metode mengajar yang mengatur pengajaran sedemikian rupa sehingga anak memperoleh pengetahuan yang belum diketahuinya itu tidak melalui pemberitahuan, sebagian atau seluruhnya ditemukan sendiri.

Dengan demikian, berdasarkan pengertian di atas dapat disimpulkan bahwa pembelajaran Discovery Learning adalah suatu model untuk mengembangkan cara belajar siswa aktif dengan menemukan sendiri, menyelidiki sendiri, maka hasil yang diperoleh akan setia dan tahan lama dalam ingatan, tidak akan mudah dilupakan siswa.

\section{b. Karakteristik dan Tujuan Discovery Learning}

Menurut Nurhadi (2006), ciri atau karakteristik Discovery Learning adalah 1) mengeksplorasi dan memecahkan masalah untuk menciptakan, mengabungkan, dan menggeneralisasi pengetahuan; 2) berpusat pada siswa; 3) kegiatan untuk menggabungkan pengetahuan baru dan pengetahuan yang sudah ada. Sedangkan menurut Bell (dalam Al-Muchtar, 2007), metode Discovery Learning meliliki tujuan melatih siswa untuk mandiri dan kreatif, antara lain sebagai berikut:

1) Dalam penemuan siswa memiliki kesempatan untuk terlibat secara aktif dalam pembelajaran. Kenyataan menunjukan bahwa partisipasi banyak siswa dalam pembelajaran meningkat ketika penemuan digunakan.

2) Melalui pembelajaran dengan penemuan, siswa belajar menemukan pola dalam situasi konkrit maupun abstrak, juga siswa banyak meramalkan (extrapolate) informasi tambahan yang diberikan.

3) Siswa juga belajar merumuskan strategi tanya jawab yang tidak rancu dan menggunakan tanya jawab untuk memperoleh informasi yang bermanfaat dalam menemukan.

4) Pembelajaran dengan penemuan membantu siswa membentuk cara kerja bersama yang efektif, saling membagi informasi, serta mendengar dan menggunakan ide-ide orang lain.

5) Terdapat beberapa fakta yang menunjukan bahwa keterampilan-keterampilan, konsep-konsep dan prinsip-prinsip yang dipelajari melalui penemuan lebih bermakna.

6) Keterampilan yang dipelajari dalam situasi belajar penemuan dalam beberapa kasus, lebih mudah ditransfer untuk aktifitas baru dan diaplikasikan dalam situasi belajar yang baru.

\section{c. Langkah-Langkah Pembelajaran Discovery Learning}

Adapun menurut menurut Lie (2002: 34-35) menyatakan bahwa dalam mengaplikasikan pembelajaran Discovery Learning di kelas tahapan atau prosedur yang harus dilaksanakan dalam kegiatan belajar mengajar sebagai berikut: 
SEUNEUBOK LADA

Jurnal Ilmu-Ilmu Sejarah, Sosial, Budaya dan Kependidikan, 7 (1), 2020: 107-117

ISSN : 2356-0770

e-ISSN : 2685-2705

1) Stimulation (stimulasi/pemberian rangsangan).

Stimulation pada tahap ini berfungsi untuk menyediakan kondisi interaksi belajar yang dapat mengembangkan dan membantu siswa dalam mengeksplorasi bahan.

2) Problem statement (pernyataan/identifikasi masalah).

Guru memberi kesempatan kepada siswa untuk mengidentifikasi sebanyak mungkin agenda masalah yang relevan dengan bahan pelajaran, kemudian salah satunya dipilih dan dirumuskan dalam bentuk hipotesis (jawaban sementara atas pertanyaan masalah)

3) Data collection (pengumpulan data).

Pada tahap ini berfungsi untuk menjawab pertanyaan atau membuktikan benar tidak hipotesis, dengan demikian anak didik diberi kesempatan untuk mengumpulkan (collection) berbagai informasi yang relevan.

4) Data processing (pengolahan data).

Data processing merupakan kegiatan mengolah data dan informasi yang telah diperoleh para siswa baik melalui wawancara, observasi, dan sebagainya, lalu ditafsirkan.

5) Verification (pembuktian).

Verification bertujuan agar proses belajar akan berjalan dengan baik dan kreatif jika guru memberikan kesempatan kepada siswa untuk menemukan suatu konsep, teori, aturan atau pemahaman melalui contoh-contoh yang ia jumpai dalam kehidupannya.

6) Generalization (menarik kesimpulan/generalisasi)

Tahap generalitation/ menarik kesimpulan adalah proses menarik sebuah kesimpulan yang dapat dijadikan prinsip umum dan berlaku untuk semua kejadian atau masalah yang sama.

\section{d. Kelebihan dan Kekurangan Pembelajaran Discovery Learning}

Berikut Al-Muchtar (2007: 79) menyebutkan terdapat beberapa kelebihan atau keunggulan model pembelajaran Discovery Learning, yaitu:

1) Siswa aktif dalam kegiatan belajar, sebab ia berpikir dan menggunakan kemampuan untuk menemukan hasil akhir.

2) Siswa memahami benar bahan pelajarannya, sebab mengalami sendiri proses menemukannya. Sesuatu yang diperoleh dengan cara ini lebih lama untuk diingat.

3) Menemukan sendiri bisa menimbulkan rasa puas. Kepuasan batin ini mendorongnya untuk melakukan penemuan lagi sehingga minat belajarnya meningkat.

4) Siswa yang memperoleh pengetahuan dengan metode penemuan akan lebih mampu mentransfer pengetahuannya ke berbagai konteks.

5) Metode ini melatih siswa untuk lebih banyak belajar sendiri.

Sedangkan menurut Nurhadi (2006: 64-65), model pembelajaran Discovery Learning juga memiliki beberapa kelemahan atau kekurangan, antara lain sebagai berikut:

1) Model ini menimbulkan asumsi bahwa ada kesiapan pikiran untuk belajar. Bagi siswa yang kurang pandai, akan mengalami kesulitan abstrak atau 
berfikir atau mengungkapkan hubungan antara konsep-konsep, yang tertulis atau lisan, sehingga pada gilirannya akan menimbulkan frustasi.

2) Model ini tidak efisien untuk mengajar jumlah siswa yang banyak, karena membutuhkan waktu yang lama untuk membantu mereka menemukan teori untuk pemecahan masalah lainnya.

3) Harapan-harapan yang terkandung dalam metode ini dapat buyar berhadapan dengan siswa dan guru yang telah terbiasa dengan cara-cara belajar yang lama.

4) Pengajaran discovery lebih cocok untuk mengembangkan pemahaman, sedangkan mengembangkan aspek konsep, keterampilan dan emosi secara keseluruhan kurang mendapat perhatian.

5) Pada beberapa disiplin ilmu, misalnya PAI kurang fasilitas untuk mengukur gagasan yang dikemukakan oleh para siswa.

6) Tidak menyediakan kesempatan-kesempatan untuk berfikir yang akan ditemukan oleh siswa karena telah dipilih terlebih dahulu oleh guru.

\section{PEMBAHASAN}

Berdasarkan hasil penelitian dapat dinyatakan bahwa pembelajaran discovery learning dapat meningkatkan hasil belajar PAI khususnya penguasaan kompetensi dasar mengenal sifat-sifat Allah pada kelas VII-A SMPN 1 Darul Aman Kabupaten Aceh Timur semester I tahun pelajaran 2018-2019. Hal tersebut dapat dianalisis dan dibahas sebagai berikut.

\section{Pembahasan Hasil Belajar Kondisi Awal}

Pada awalnya siswa kelas VII-A, nilai rata-rata pelajaran PAI rendah khususnya pada kompetensi mengenal sifat-sifat Allah. Yang jelas salah satunya disebabkan karena luasnya kompetensi yang harus dikuasainya dan perlu daya ingat yang setia sehingga mampu menghafal dalam jangka waktu lama. Sebelum dilakukan tindakan guru memberi tes. Berdasarkan ketuntasan belajar siswa dari sejumlah 31 siswa terdapat 6 atau 19,35\% yang baru mencapai ketuntasan belajar dengan skor standar Kriteria Ketuntasan Minimal. Sedangkan 25 siswa atau $80,64 \%$ belum mencapai kriteria ketuntasan minimal yang telah ditentukan yaitu sebesar 70. Sedangkan hasil nilai kondisi awal I terdapat nilai tertinggi adalah 8 , nilai terendah 2, dengan rata-rata kelas sebesar 4,83.

Proses pembelajaran pada kondisi awal menunjukkan bahwa siswa masih pasif, karena tidak diberi respon yang menantang. Siswa masih bekerja secara individual, tidak tampak kreatifitas siswa maupun gagasan yang muncul. Siswa terlihat jenuh dan bosan tanpa termotivasi karena pembelajaran selalu monoton.

\section{Pembahasan Hasil Belajar Siklus I}

Dari hasil tes siklus I, menunjukkan bahwa hasil yang mencapai nilai A (sangat baik) adalah 5 siswa (11,1\%), sedangkan yang mendapat nilai B (baik) adalah 12 siswa atau (50,0 \%), sedangkan dari jumlah 40 siswa yang masih mendapatkan nilai C (cukup) sebanyak 17 siswa (33,3\%), sedangkan yang 
SEUNEUBOK LADA

Jurnal Ilmu-Ilmu Sejarah, Sosial, Budaya dan Kependidikan, 7 (1), 2020: 107-117

ISSN : 2356-0770

e-ISSN : 2685-2705

mendapat nilai D (kurang) ada 6 siswa $(5,6 \%)$, sedangkan yang mendapat nilai D (sangat kurang) tidak ada atau $0 \%$.

Berdasarkan ketuntasan belajar siswa dari sejumlah 40 siswa terdapat 7 atau $38,88 \%$ yang sudah mencapai ketuntasan belajar. Sedangkan 11 siswa atau $61,11 \%$ belum mencapai ketuntasan. Adapun dari Hasil nilai siklus I dapat dijelaskan bahwa perolehan nilai tertinggi adalah 8 , nilai terendah 2 , dengan nilai rata-rata kelas sebesar 6,67.

Proses pembelajaran pada siklus I sudah menunjukkan adanya perubahan, meskipun belum semua siswa terlibat aktif dalam kegiatan pembelajaran . Hal ini dikarenakan kegiatan yang bersifat kelompok ada anggapan bahwa prestasi maupun nilai yang di dapat secara kelompok . Dari hasil pengamatan telah terjadi kreatifitas dan keaktifan siswa secara mental maupun motorik, karena kegiatan pembelajaran yang dilakukan dengan permainan serta perlu kecermatan dan ketepatan . Ada interaksi antar siswa secara individu maupun kelompok, serta antar kelompok. Masing-masing siswa ada peningkatan latihan bertanya dan menjwab antar kelompok, sehingga terlatih ketrampilan bertanya jawab. Terjalin kerjasama intern dan antar kelompok. Ada persaingan positif antar kelompok mereka saling berkompetisi untuk memperoleh penghargaan dan menunjukkan untuk jati diri pada siswa.

Dengan demikian penelitian dilanjutkan pada siklus II dengan mengacu kekurangan dan kelemahan pada siklus I. Berdasarkan analisis tersebut maka penelitian ini dilanjutkan ke siklus II.

\section{Pembahasan Hasil Belajar Siklus II}

Dari pelaksanan tindakan siklus II dapat diketahui bahwa yang mendapatkan nilai sangat baik (A) adalah 22,58 \% atau 7 siswa, sedangkan yang terbanyak yaitu yang mendapat nilai baik (B) adalah 64,52\% atau 20 siswa. Dan yang mendapat nilai C (cukup) adalah 12,90\% atau sebanyak 4 siswa.Sedangjkan yang mendapat nilai D dan E tidak ada. Sedangkan nilai rata-rata kelas 7,66.

Proses pembelajaran pada siklus II sudah menunjukkan semua siswa terlibat aktif dalam kegiatan pembelajaran. Hal ini dikarenakan sekalipun kegiatan bersifat kelompok namun ada tugas individual yang harus dipertanggung jawabkan, karena ada kompetisi kelompok maupun kompetisi individu. Dari hasil pengamatan telah terjadi kreatifitas dan keaktifan siswa secara mental maupun motorik, karena kegiatan pembelajaran yang dilakukan dengan permainan perlu kecermatan dan ketepatan. Ada interaksi antar siswa secara individu maupun kelompok, serta antar kelompok. Masing- masing siswa ada peningkatan latihan bertanya jawab dan bisa mengkaitkan dengan mata pelajaran lain maupun pengetahuan umum, sehingga disamping terlatih ketrampilan bertanya jawab , siswa terlatih berargumentasi. Ada persaingan positif antar kelompok untuk penghargaan dan menunjukkan jati diri pada siswa. 
Hasil antara siklusI dengan siklus II ada perubahan secara signifikan, hal ini ditandai dengan peningkatan jumlah siswa yang mencapai ketuntasan belajar. Dari hasil tes akhir siklus II ternyata lebih baik dibandingkan dengan tingkat ketuntasan belajar siswa pada siklus I.

Agar lebih jelas gambaran perbandingan peningkatan kegiatan siswa dan hasil belajar siswa dari kondisi awal, siklus I dan siklus II, dapat dilihat dan diperhatikan pada rekapitulasi tabel dan grafik ketuntasan belajar di bawah ini:

Tabel 1.1 Rangkuman Ketuntasan Belajar Pada Kondisi Awal, Siklus I, dan II

\begin{tabular}{|l|l|c|c|c|c|c|c|}
\hline \multirow{2}{*}{ No } & \multirow{2}{*}{ Hasil Tes akhir } & \multicolumn{3}{|c|}{ Siklus } & \multicolumn{3}{c|}{ Presentase } \\
\cline { 3 - 8 } & & $\begin{array}{c}\text { Kondisi } \\
\text { Awal }\end{array}$ & I & II & $\begin{array}{c}\text { Kondisi } \\
\text { Awal }\end{array}$ & I & II \\
\hline 1. & Siswa yang tuntas & 6 & 16 & 27 & $19,35 \%$ & $51,61 \%$ & $87,10 \%$ \\
\hline 2. & Siswa yang tidak tuntas & 25 & 15 & 4 & $80,65 \%$ & $48,39 \%$ & $12,90 \%$ \\
\hline 3 & Jumlah & 31 & 31 & 31 & $100 \%$ & $100 \%$ & $100 \%$ \\
\hline
\end{tabular}

Tabel 1.2 Rekapitulasi Perolehan Nilai Kondisi Awal, Siklus I, dan II

\begin{tabular}{|l|l|c|c|c|}
\hline \multirow{2}{*}{ No } & \multicolumn{2}{|c|}{ Keterangan } & \multicolumn{3}{|c|}{ Nilai } \\
\cline { 3 - 5 } & $\begin{array}{c}\text { Kondisi } \\
\text { Awal }\end{array}$ & Siklus I & Siklus II \\
\hline 1 & Nilai Tertinggi & 80 & 90 & 100 \\
\hline 2 & Nilai Terendah & 20 & 40 & 50 \\
\hline 3 & Nilai Rata-rata & 40,83 & 60,67 & 70,66 \\
\hline
\end{tabular}

Rekapitulasi persentase perbandingan peningkatan hasil belajar pada kondisi awal, siklus I dan siklus II pada tabel diatas dapat diperjelas melalui gambar grafik sebagai berikut.

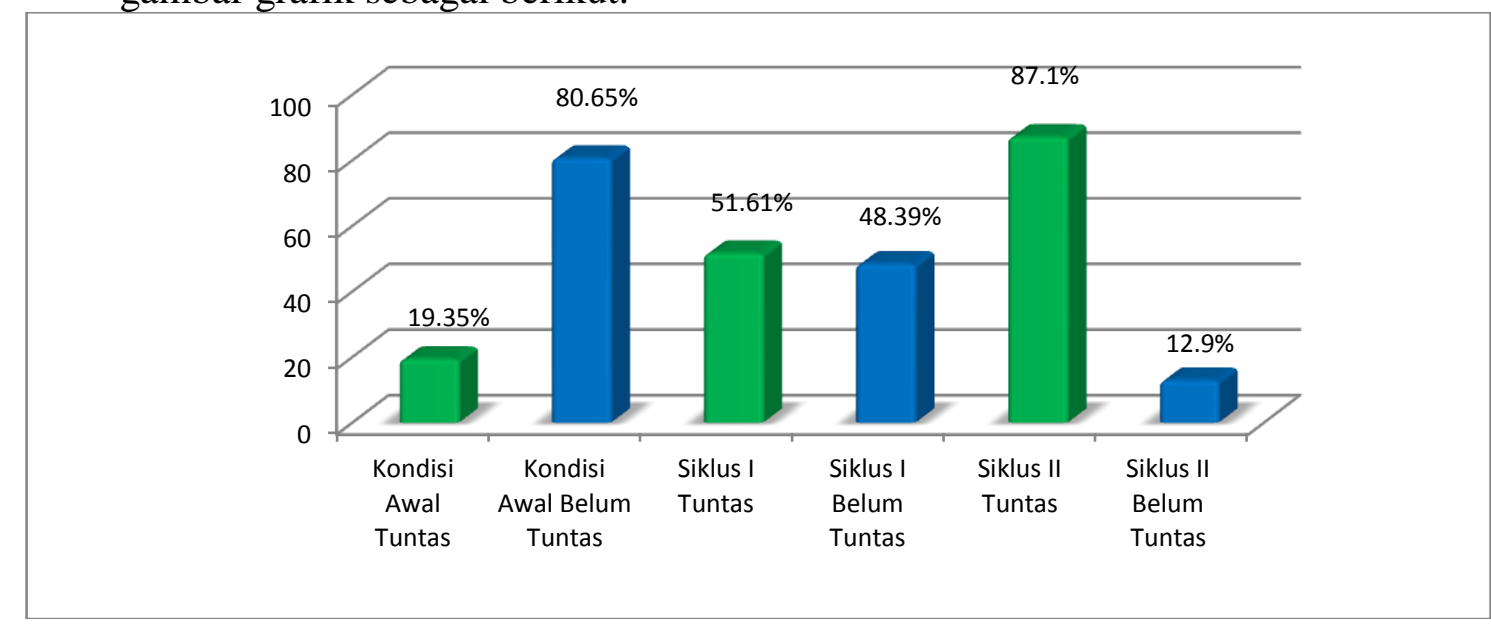

Gambar 1.1 Grafik Rangkuman Ketuntasan Belajar Kondisi Awal, Siklus I, dan Siklus II 
SEUNEUBOK LADA

Jurnal Ilmu-Ilmu Sejarah, Sosial, Budaya dan Kependidikan, 7 (1), 2020: 107-117

ISSN : 2356-0770

e-ISSN : 2685-2705

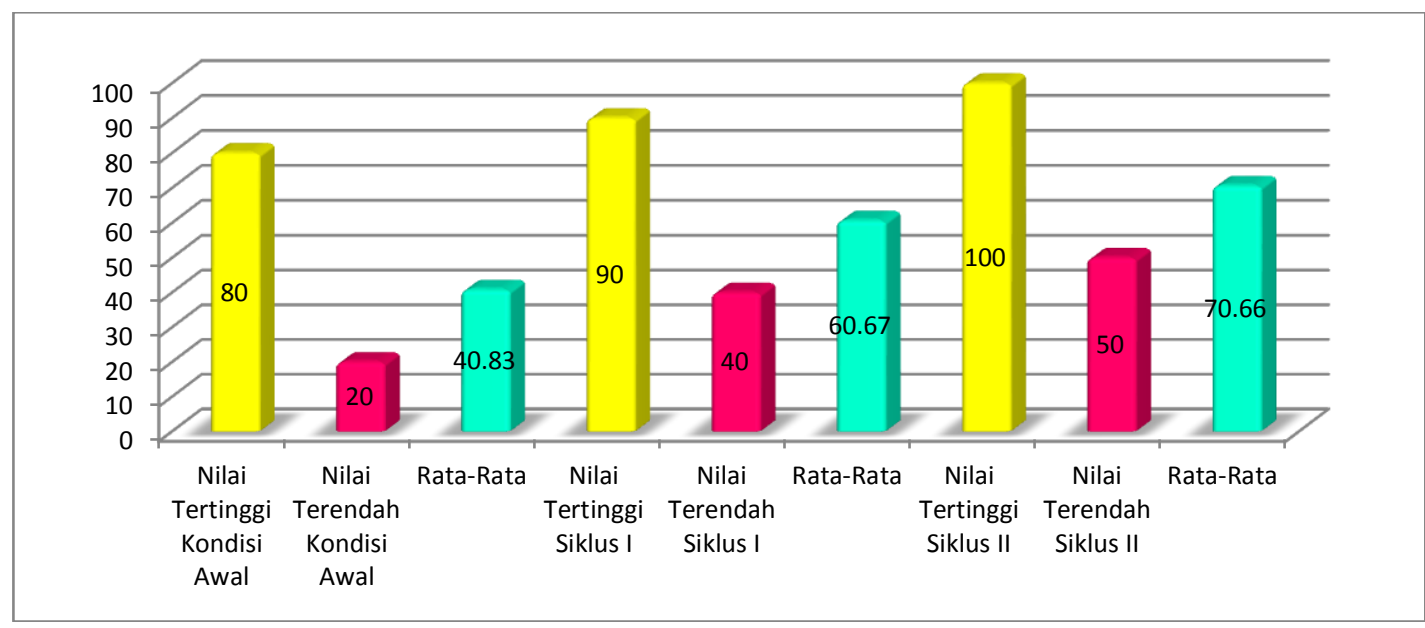

\section{Gambar 1.2}

Grafik Rekapitulasi Perolehan Nilai Kondisi Awal, Siklus I, dan Siklus II

Dari hasil penelitian, dapat dilihat dan telah terjadi peningkatan pemahaman mengenal sifat-sifat Allah terhadap siswa kelas VII-A SMPN 1 Darul Aman Kabupaten Aceh Timur pada semester I tahun pelajaran 2018-2019 melalui penerapan pembelajaran discovery learning. Peningkatan nilai rata- rata yaitu 4,83 pada kondisi awal menjadi 6,67 pada siklus I dan menjadi 7,66 pada siklus II. Nilai rata-rata siklus I meningkat 38,09 \% dari kondisi awal, nilai rata-rata siklus II meningkat 24,84\% dari siklus I. Sedangkan ketuntasan belajar pada siklus I ada peningkatan sebesar 23,37 \% dari kondisi awal, siklus II meningkat 28,62 \% dari siklus II. Peningkatan nilai rata-rata kelas secara keseluruhan sebesar 58,59\% .

Pada akhir pembelajaran terdapat perubahan positif pada siswa mengenai pemahaman mengenal sifat-sifat Allah. Dengan menggunakan pembelajaran discovery learning ternyata mampu meningkatkan prestasi belajar PAI pada kompetensi dasar mengenal sifat-sifat Allah. Dengan demikian nilai rata-rata siklus II sudah melampaui KKM yang ditetapkan yaitu 70 .

\section{SIMPULAN}

Berdasarkan penelitian ini dapat disimpulkan bahwa penerapan Pembelajaran Discovery Learning dapat meningkatkan hasil belajar mata pelajaran PAI khususnya kompetensi dasar mengenal sifat-sifat Allah bagi siswa kelas VII-A SMPN 1 Darul Aman Kabupaten Aceh Timur tahun ajaran 2017/ 2018. Pada akhir siklus I, siswa yang mencapai ketuntasan belajar sebanyak $51,61 \%$ (16 anak), dan siswa yang belum tuntas sebanyak 48,39\% (15 anak), sedangkan pada akhir siklus II, sebanyak 87,10\% (27 anak) dan sebanyak 12,90\% ( 4 anak) belum mencapai ketuntasan belajar. Dengan nilai rata- rata kelas siklus I 6,67 dan rata- rata kelas siklus II 7,66. Adapun hasil non tes pengamatan proses belajar menunjukkan perubahan siswa lebih aktif selama proses pembelajaran berlangsung. Secara keseluruhan rata-rata kelas mencapai kenaikan sebesar 
$58,59 \%$, dan ketuntasan belajar siswa secara keseluruhan mencapai peningkatan sebesar 55,3\% jika dibandingkan dengan kondisi awal.

\section{DAFTAR PUSTAKA}

Al-Muchtar, J. 2007. Pengajaran Discovery. Surabaya: Pusat Sains dan Matematika Sekolah, Program Pascasarjana, University Press.

Dimyati dan Mudjiono, 2002. Strategi Belajar Mengajar. Jakarta: Depdikbud.

Euharini, dkk. 2007. Pengembangan Pendidikan Agama Islam. Jakarta: Rineka Cipta.

Hamalik, O.2003. Metode Mengajar dan Kesulitan-Kesulitan Belajar. Bandung: Tarsito.

Hidayat, K, 2002. Active Learning. Yogyakarta: Yappendi.

Ibrahim, M. 2012. Model Pembelajaran Discovery. Surabaya: Unesa University Press.

Lie, A. 2002. Discovery Learning. Jakarta: Grasindo.

Nurhadi. 2006. Pembelajaran Kontekstual dan Penerapannya. Malang: Universitas Negeri Malang. 